\title{
Rural Economic Empowerment Based on One Village One Product (OVOP)
}

\author{
Endang Murti ${ }^{1} \quad$ Harianto $^{1} \quad$ Sutawa $^{2}$ \\ 1.Faculty of Social and Political Sciences, University Merdeka Madiun, Indonesia \\ 2.Faculty of Economic, University Soeryo Ngawi, Indonesia
}

\begin{abstract}
.
The people's economic development has a very important role in supporting the national economy, because people's economy has a strong resilience in facing the global economic crisis. Meanwhile, the people's economic sector is mostly carried out by village communities who have the uniqueness and uniqueness of the products produced by each village, so it is very possible to develop into superior village products. Only the problem of the people's economic sector is that there is still relatively limited access to capital and technology used, resulting in low competitiveness in facing the current era of globalization. The "One village on product" approach can be developed as an alternative economic development strategy for the people, although it is necessary to revitalize the concept in accordance with the characteristics of each sector of the people's economy. One of the main elements in one village one product is the development of superior village products, which have a basis for local values and local culture. These characteristics are advantages that can be developed extensively through a touch of modernization, in order to have the competitiveness to enter modern markets. For this reason, a commitment from the central and regional governments is needed in order to facilitate development. With the development of the people's economic sector will encourage equitable distribution of people's income and at the same time can improve people's welfare.
\end{abstract}

Keywords: People's economy, local government, coaching, ovop, welfare.

DOI: $10.7176 /$ RHSS/9-12-17

Publication date: June $30^{\text {th }} 2019$

\section{INTRUDUCTION.}

The era of globalization has consequences for future economic development, because with the development of knowledge and information technology makes access to information easier, so it is very possible that there will be increased economic mobility both from within and from outside. Therefore, in facing the challenges of globalization, an economic development strategy is needed that emphasizes the role of the people's economy as the basis of the national economy. Many emerging countries such as Taiwan, South Korea and China recognize the existence of the people's economic sector as a pillar of economic growth, investment costs to create and grow the people's economic sector are relatively small but the impact can encourage economic equality to all levels of society. For this reason, economic development must be oriented towards the development of the people's economy through efforts to encourage and foster initiative, creativity and innovation to anticipate the current globalization competition. According to Wharton in Mardikanto and Poerwoko S. (2017: 134) economic empowerment is the existence of a continuum of economic behavior that moves from a moral subsystem which is generally not responsive to innovations offered towards rational economic morals that are very responsive to change. These demands for change must make attention in the development of the people's economy, especially changes that lead to the quality of the products produced, so that the people's economy has a high competitiveness to win global economic competition.

Meanwhile, the national development policy so far, which emphasizes more on the development of industrialization, is apparently unable to encourage even distribution of economic growth, and even tends to generate income disparities, especially for the lower classes of society. The tricle down effect theory is expected to be able to drip the results of industrial development throughout the society, precisely those who are able to enjoy only certain groups of people, while for the lower classes with all their limitations they do not have the ability to utilize the results of industrial development so far. as a result the rich are getting richer, and the poor are getting poorer. For this reason, a balance of economic business opportunities is needed for the society, through the development of the people's economic sector. According to Korten (1984) in Sun'an and Abdurrahman (2015: 122), such a development model is in line with the notion of development that supports the people, where there is an emphasis on the importance of initiatives and local differences. Therefore, such development emphasizes a selforganization system developed around self-reliant human-scale organizational units and communities. Furthermore, Sun'an and Abdurrahman (2015: 121), explained: one of the pillars of popular economy is the existence of small and medium scale economic enterprises (UKM) which have been the foundation of most of the workforce in Indonesia. The SMEs are mostly employed by most economic actors in Indonesia for several reasons, including relatively small amounts of capital, not high skill levels, and uncomplicated licenses. Meanwhile, the characteristics of the people's economic structure are usually home-based businesses that are nuanced with local 
superior products, with small-scale production, relatively limited marketing range, and technology used is still traditional technology, and does not require high skills and education. For this reason, in developing the economic sector the people need to adjust to the character of the people's economic structure, based on the potential of local resources, local values, and local culture.

The one village one product approach can be an alternative model for the development of the people's economic sector based on the superior products of the village. The OVOP movement (One Village One Product) developed and implemented by both Japan and Thailand with OTOP, shows its success through the development of MSMEs that can produce products that are of high quality and have competitiveness globally. With the development of MSMEs it can be a competitive solution for products from outside and at the same time become a driver of growth in a region. OVOP is intended as an approach in moving the economy of a region through the development of superior products based on local potential. Excellent products are a characteristic feature of a region with its unique culture and tradition which can be a special attraction that allows to reach a broad marketing aspect. Through intensive guidance from the government, it is expected to be able to improve the quality of new packaging products, so that they have high global competitiveness. With the development of typical products of an area, it is expected to be able to sustain the economy of the community and can increase the income of the community and at the same time be able to overcome the problem of community poverty. According to Morihiko Hiramatsu as the initiator of OVOP, there are 3 main OVOP principles, including: (1) Local yet global; that is how society can think Global by acting locally. In the beginning, the community developed good / unique products with superior quality, good packaging, extraordinary benefits that cannot be replaced with other products / product differential. Gradually, these products can have fanatical consumers in the country who later develop into the export market. (2) Self-reliance and creativity; The government provides various facilities only for product development with tightly selected competitive programs. OVOP is intended not one village one product but each village chooses one product facilitated by the government to be developed. The OVOP program avoids assistance that will injure the spirit of independence, creativity and community innovation that hinders the success of the OVOP program long-term. (3) Human resources development; that the development of the capacity of Human Resources (HR) must always be carried out to keep up with the times; technology, products, fashion and design (Wahyudi, 2016). However, in its implementation, the OVOP approach needs to be revitalized to fit the village economic potential in general, because each village has certain superior products that are characteristic of its distinctiveness. If the superior products of each village can be facilitated by the local government, it can become a promising potential to improve the welfare of the village community. From the aspect of product quality, processed products from rural communities still need to be completely modified so that product quality can be more qualified, and from the aspect of product packaging still need to get a touch of modern aesthetics in order to have competitive competitiveness when promoted in modern markets, and from aspects Its marketing needs to get government guidance so that it can utilize the market segment oneline. Therefore, so that the superior products of each village can become a driver of the village economy, it takes the commitment of the government through intensive guidance and at the same time provides access to more opportunities and opportunities to promote the community, especially communities outside the region. With the development of superior products each village can become a global competition bumper which is currently very heavy in the national economic sector, and at the same time can be a solution to overcome the problem of poverty, unemployment, by increasing the mobility of rural economic enterprises, so as to increase people's income and welfare village in general.

\section{LITERATURE REVIEW}

\section{Village Economic Empowerment}

In facing the challenges of globalization, populist economy is one of the pillars of the national economy, which is a small and medium scale economic enterprise (MSME). MSMEs are mostly carried out by lower-income economic actors, because in their business activities they do not require large business capital, do not require highly skilled workforce, do not need high technology, and also do not require convoluted permits. The characteristics of these MSMEs make a significant amount of growth carried out by most of the lower classes, and even with the existence of MSMEs, they are recognized or unable to open large jobs. However, with the development of the large number of MSMEs, it was only a relatively small contribution to national economic growth. According to Sun'an and Abdurrahman (2015: 121), that: in fact every economic policy produced by the government (central / regional) must consider two sides, namely the goal of creating social justice and compromising it with economic growth. In some cases, the objectives of social justice and economic growth are trade-offs, so caution is needed to take these economic policies. According to Ismail (1995), there are two things that need to be noted from this thought; First, people's participation is an absolute element in a people's dimension of development. In this case, the task of the government is only as a facilitator, namely creating conditions that encourage people's initiatives in meeting their own needs and in solving the problems they face. Second, what the people want is the best choice for their country, both in terms of their goals and ways to achieve goals (Sun'an and Abdurrahman, 2015: 123). 
People's economic empowerment must be a commitment and policy of all departments, because the dimensions that must be handled are multi. Sumodiningrat (1999), explains that: the concept of economic empowerment in a nutshell is: (1). The economy that is organized by the people is that the national economy is rooted in the potential and strength of society at large to run the wheels of their own economy. Understanding the people is all citizens. (2). Community economic empowerment is an effort to make the economy strong, large, modern and highly competitive in the right market mechanism. Because the constraints of people's economic development are structural constraints, the empowerment of the people's economy must be carried out through structural change. (3). The structural change in question is the change from a traditional economy to a modern economy, from a weak economy to a strong economy, from a subsistence economy to a market economy, from dependence to independence. The steps in the structure change process include: allocating resources for resource empowerment; institutional strengthening; mastery of technology; and empowering human resources. (4). Empowerment of the people's economy is not enough just to increase productivity, provide equal business opportunities, and only provide capital injections as a formula, but there must be close cooperation and partnership between those who have advanced and those who are still weak and undeveloped. (5). Its policies in people's economic development are: providing opportunities or greater access to production assets (especially capital); strengthen the position of transactions and people's economic business partnerships, so that the people's economic actors are not merely price takers; education and health services; strengthening of small industries; encourage the emergence of new entrepreneurs; and spatial equality. (6). Community empowerment activities include: increasing access to business capital assistance; increasing access to HR development; and increased access to facilities and infrastructure that directly support the socio-economic conditions of local communities. Further explained, from the six main points concerning the concept of community economic empowerment, it can be concluded, that: (1) community empowerment cannot be done only through a leaf approach, or just a branch, or just a stem, or just a root; because the problems faced are indeed in each aspect; (2) community empowerment in the economic field, is not enough just to provide revolving capital, but also there must be community economic institutional strengthening, strengthening human resources, providing infrastructure, and strengthening the bargaining position; (3) community empowerment in the economic field or strengthening the people's economy, must be carried out elegantly without inhibiting and discriminating against a strong economy; For this reason, partnerships between micro-enterprises, medium-scale small-scale businesses, and large-scale businesses are ways that must be taken; (4) community empowerment in the economic field is the process of strengthening the people's economy towards a strong, modern, efficient people's economy; and (5) community empowerment in the economic field, cannot be done through an individual approach, but must be through a group approach (Mardi Yatmo Hutomo, 2000).

\section{One Village One product}

OVOP can be part of the elaboration of the concept of popular economy, where people's economy itself is an economic system that emphasizes the dimensions of justice in the control of economic resources, the process of production and consumption. In this populist economy people's prosperity takes precedence over the prosperity of individuals. The concept of populist economic development is translated into operational programs based on the domestic economy at the district and city levels with high levels of independence. However, it needs to be emphasized that the development of populist economy in the current era of autonomization does not have to be translated into a territorial perspective, but should be developed in the perspective of 'regionalization' in which integrated unity of potential, excellence, opportunity, and socio-cultural character. The manifestation of this people's economy is the birth of MSMEs and cooperatives as pillars of economic development. Strengthening these pillars is certainly a necessity to achieve the basic objectives of the principle of people's economy, and the concept of One Village One Product (OVOP) can be a policy in strengthening the pillars of this people's economy.

The OVOP movement aims to improve the welfare of the community, especially at the village level through a series of productive business activities to increase the income of the community. As one of the efforts carried out is increasing the values of superior local or domestic products that can compete in the market with increasing quality and quality in order to be able to compete in domestic and international markets. OVOP is an integrative program that seeks to increase self-confidence in the capabilities of the community and increase public awareness of the potential and wealth of its territory. Local specialty products that have been carried out for generations can be extracted and developed to produce high value-added products both natural resources and local cultural products that have potential markets and exports (Andriani, 2017: 13). Thus the One Village One Product Program (OVOP) is a collaborative governance-based program that is oriented to improving the rural economy through increasing the income of the community at the grassroots level and helping the development of the capacity of rural communities on certain products and to identify local potentials in each region and encourage regions to be able to bring up their flagship products.

In an effort to start the OVOP movement, it is necessary to understand some of the bases so that the OVOP movement does not become a sinking movement. There are three main principles proclaimed by Mr. Hiramatsu, (Sugiharto and Rizal, 2008, p7); (Panggabean, 2011), namely: (1). Local but global, the more local means the more 
global. That is, commodities or products of a local nature can turn out to be commodities or products that go international. The OVOP Movement development is aimed at developing and marketing a product that can be a source of pride for the local people. (2). Independence and creativity. The deterrent from the movement is the citizens themselves. It is not Government officials who must determine local specific products that must be selected and developed, but must be the people's choice to revitalize their area. An important point that needs to be taken into consideration is not to provide subsidies directly to the local community. (3). Human resource development is the most important component of this movement's campaign. It is not the Government, but it is the citizens of the community who must produce distinctiveness. Thus, the existing human resources and the community must be given knowledge about the OVOP movement and the introduction of existing regional potential so that they can be the driving force of the OVOP movement in the region. We must be able to encourage innovative human resources who are capable of carrying out new challenges in the agriculture, marketing, tourism and other fields. In its implementation, the OVOP movement can be adjusted to the character and purpose of empowering rural economic potential. In the local but global element in this movement is intended for products produced by rural communities that have privileges, uniqueness or distinctiveness, so that it is a characteristic that does not exist with other regions or communities. Uniqueness is a very strong attraction for people from both inside and outside the country to know and get to know this community more closely, so that privilege becomes a strong selling point to bring in many people or communities. In the element of independence and creativity, the OVOP movement must begin with the wishes of the community members so that the products set are the choices of the community members themselves. And on the element of human resource development, it is intended that there is a commitment of the local government to provide guidance so that they have the knowledge and ability to develop the products produced, as well as the government's commitment to facilitate the marketing of the products of the village community.

From the two concepts of thought above, it can be stated as a hypothesis in this study, are:

$H o=$ There is no relationship between the OVOP strategy (One Village One Product) towards empowering the village economy,

$H a=$ There is a relationship between the OVOP strategy (One Village One Product) towards empowering the village economy.

While the focus and direction of this research can be illustrated in the diagram as follows:

Picture. 1

OVOP Strategy relationship orientation (one Village One Product) and Village Economic Empowerment

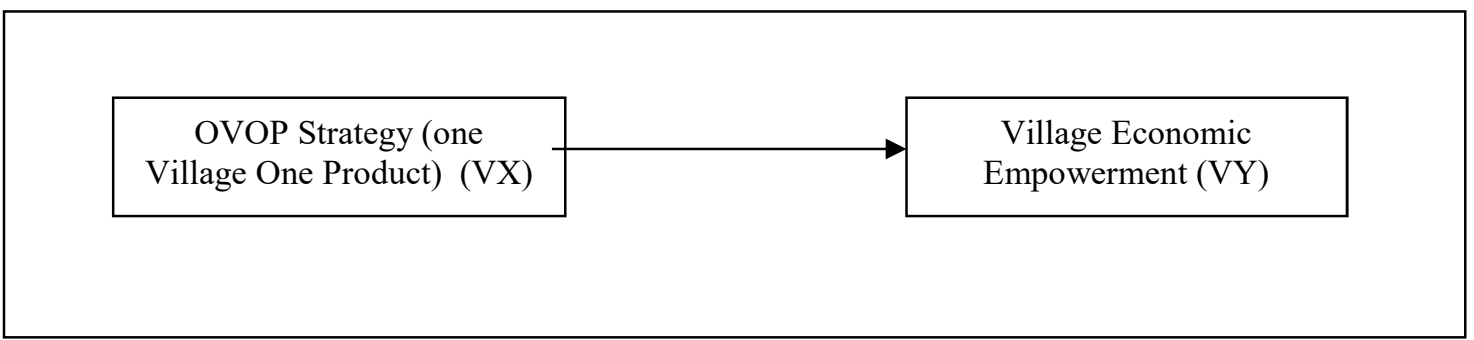

\section{RESEARCH METHODS}

This study uses a quantitative approach to determine respondents' assessment of the OVOP (One Village One Product) strategy, and empowering the village economy. Data was collected through distributing questionnaires to 120 respondents who were randomly selected in 6 villages in Ngawi Regency. Each village was assigned 20 respondents by stratified random sampling, which consisted of: village heads and village officials, BPD, LKMD, PKK, and village community MSMEs. Respondents' assessment was measured using a Likert scale with gradations from very positive to very negative, in the form of words such as: a) Strongly agree with a score of 5 , b) agree with a score of 4, c) Hesitate with a score of 3,d) No agree with the score 2, and e) Strongly disagree with the score 1 . While the method of data analysis uses a regression analysis model with processing through SPSS.

\section{RESULTS AND DISCUSSION.}

\section{Correlation Test}

For the hypothesis test, a correlation test between OVOP (VX) strategy variables is used as an independent variable for village economic empowerment (VY) as the dependent variable. The correlation test results are as follows: 
Table. 1

Relationship of OVOP Strategy (one Village One Product) towards Village Economic Empowerment

\section{Correlations}

\begin{tabular}{|ll|r|r|}
\hline & OVOP Strategy & $\begin{array}{r}\text { Village Economic } \\
\text { Empowerment }\end{array}$ \\
\hline OVOP Strategy & Pearson Correlation & 1 & $.852^{* *}$ \\
& Sig. (2-tailed) & 120 & .000 \\
& $\mathrm{~N}$ & $.852^{* *}$ & 120 \\
\hline Village Economic & Pearson Correlation & .000 & 1 \\
Empowerment & Sig. (2-tailed) & 120 & 120 \\
Village Economic & $\mathrm{N}$ & & \\
Empowerment & & & \\
\hline
\end{tabular}

**. Correlation is significant at the 0.01 level (2-tailed).

From the table above, the value of the correlation between the ovop strategy variable and the village economic empowerment variable is 0.852 with a value of pvalue $=0,000$. When compared with the value of $\alpha=$ 0.05 , it is known that $\mathrm{p}$ value $=(0,000)<\alpha(0.05)$. Thus, the Ha hypothesis is accepted, namely there is a correlation between the OVOP strategy and village economic empowerment.

\section{Regression Test}

The results of the regression calculation between OVOP strategy variables on village economic empowerment, are:

Table. 2

Effect of OVOP Strategy (one Village One Product) towards Village Economic Empowerment

Coefficients $^{\mathrm{a}}$

\begin{tabular}{|c|c|c|c|c|c|c|}
\hline \multirow{2}{*}{\multicolumn{2}{|c|}{ Model }} & \multicolumn{2}{|c|}{ Unstandardized Coefficients } & $\begin{array}{l}\text { Standardized } \\
\text { Coefficients }\end{array}$ & \multirow[b]{2}{*}{$\mathrm{t}$} & \multirow[b]{2}{*}{ Sig. } \\
\hline & & $\mathrm{B}$ & Std. Error & Beta & & \\
\hline 1 & (Constant) & 1.187 & 3.235 & & .367 & .714 \\
\hline & OVOP Strategy & .970 & .055 & .852 & 17.659 & .000 \\
\hline
\end{tabular}

a. Dependent Variable: Village Economic Empowerment

From the regression equation $(\mathrm{Y}=\mathrm{a}+\mathrm{bX}$ ), it can be identified: (1) Constant value 1,187; indicates the OVOP strategy will be constant if the village economic empowerment variable is zero (none), assuming other factors remain or do not change in value. (2) The ovop strategy variable which is worth 0.970 (positive) shows the influence of ovop strategy on village economic empowerment. If the ovop strategy increases by 1 unit then the empowerment of the village economy also increases by 0.970 . Thus the ovop strategy has a positive effect on village economic empowerment.

\section{Determination Test.}

The coefficient of determination (R2) is used to measure how far the model's ability to explain variations in the dependent variable (Ghozali, 2006). The test results of the coefficient of determination are: 
Table. 3

Determination Test Results between the variables of OVOP Strategy and Village Economic Empowerment

Model Summary

\begin{tabular}{|l|r|r|r|r|}
\hline Model & $\mathrm{R}$ & \multicolumn{1}{|c|}{ R Square } & Adjusted R Square & Std. Error of the Estimate \\
\hline 1 & $.852^{\mathrm{a}}$ & .725 & .723 & 4.596 \\
\hline
\end{tabular}

a. Predictors: (Constant), OVOP Strategy

The amount of Multiple Coefficient of Determination ( $R$ Square) is 0.725 or $72.5 \%$ which means that village economic empowerment can be explained by ovop strategy variables, while the remaining $27.5 \%$ is explained by other variables not explained in this study. The OVOP strategy, which is intended as an alternative approach to developing the people's economic sector, has the potential to become a strategic part in empowering the people's economy, except that it needs to be revitalized to fit the characteristics of the village economic sector potential. One aspect that needs to be considered is that the village economic sector which is developed based on the natural potential produced is not based on the development of cultural potential. Therefore, the marketing reach is more potential for the interests of the domestic market, which needs to be fostered regarding the use of appropriate technology (TTG) so that the products produced are more productive and efficient. Besides that, product design needs to be well initiated so that the product packaging can enter modern markets, so that it has high competitiveness in the domestic market competition.

\section{CONCLUSION}

The people's economic sector can be a potential in driving people's economic growth, and at the same time supporting the national economy. Most of the people's economic sector as the perpetrators are the lower classes of society, so it is very strategic in order to realize economic equality. The one village one product (OVOP) approach can be a strategy to mobilize the people's economy, emphasizing village superior products, which have a base of local values and local culture as "brade brands", because that particularity is an advantage that can be developed into a product who have the competitiveness to enter modern markets. For this reason, a commitment from the central and regional governments is needed in order to facilitate development. With the development of the people's economic sector will encourage equitable distribution of people's income and at the same time can improve people's welfare.

\section{CONFLICT OF INTEREST}

There is no conflict of interest.

\section{ACKNOWLEDGMENTS}

This article is sponsored by the Kemenristik-Dikti Indonesian Research Grants Program.

\section{REFERENCES}

Andriani, Dwi Nila. 2017, Pengaruh modal, tenaga kerja, dan bahan baku terhadap ... - E-Journal, $e$ journal.unipma.ac.id/index.php/equilibrium/article/view/1543, diakses tanggal. 4 Mei 2019.

Ghozali, Imam, 2006, Aplikasi Analisis Multivariate Dengan Program SPSS, Semarang: Badan Penerbit Universitas Diponegoro.

Mardi Yatmo Hutomo, 2000, Pemberdayaan Masyarakat dalam Bidang Ekonomi, Yogyakarta: Adiyana Press.

Mardikanto dan Poerwoko S. 2017, Pemberdayaan Masyarakat Dalam Prespektif Kebijakan Public, Bandung: ALFABETA.

Sugiharto dan Rizal, 2008, Ekonomi Makro: Teori Analisis dan Kebijakan. Jakarta: Gramedia Pustaka Utama.

Sumodiningrat, Gunawan. (1999). Pemberdayaan dan Jaringan Pengaman Sosial. Jakarta: PT. Gramedia Pustaka Utama.

Sun'an, Muammil \& Abdurrahman Senuk. 2015. Ekonomi Pembangunan Daerah. Jakarta: Penerbit Mitra Wacana Media.

Wahyudi, A, 2016, Efektivitas dan Efisiensi Implementasi OVOP dalam Pengembangan ..., journal.isi.ac.id/index.php/JTKS/article/view/1811, diakses Tanggal. 4 Mei 2019 